How to cite this article:

Tan, R. M., Yangco, R. T., \& Que, E. N. (2020). Students' conceptual understanding and science process skills in an inquiry-based flipped classroom environment. Malaysian Journal of Learning \& Instruction, 17 (1), 159-184. https:// doi.org/10.32890/mjli2020.17.1.7

\title{
STUDENTS' CONCEPTUAL UNDERSTANDING AND SCIENCE PROCESS SKILLS IN AN INQUIRY-BASED FLIPPED CLASSROOM ENVIRONMENT
}

\author{
${ }^{1}$ Rolando Mango Tan, ${ }^{2}$ Rosanelia T. Yangco, ${ }^{3}$ Elenita N. Que \\ ${ }^{I}$ UP National Institute for Science and \\ Mathematics Education Development \\ ${ }^{2,3}$ University of the Philippines College of Education \\ ${ }^{1}$ Corresponding author: rmtan67@gmail.com
}

Received: 26/2/ 2019 Revised: 25/11/2019 Accepted: 6/1/2020 Published: 31/1/2020

\begin{abstract}
Purpose: The purpose of this study is to determine the impact of an Inquiry-based Flipped classroom model on the conceptual understanding and science process skills of junior high school students in the Philippines.

Method: A two-group pretest/post-test design was conducted on 55 Grade 9 students for the study. One group received instruction using the flipped classroom format while the other group serving as control was taught in the conventional format. A Conceptual Understanding Test (CUT) and a Science Process Skills Test (SPST) were used to measure the impact of instruction on the two groups. Independent samples t-test was used to determine if there was a significant difference between the groups while paired samples t-test was conducted on both groups to determine if the groups improved significantly after a 7-week intervention. Linear regression was performed to determine if science process skills was a positive predictor of conceptual understanding.
\end{abstract}

Findings: Inquiry-based flipped classroom did not make students perform better than the non-flipped inquiry-based learning 
environment in the Conceptual Understanding Test (CUT) and Science Process Skills Test (SPST) except on one biology topic (non-Mendelian Genetics) where the Flipped Inquiry Group scored significantly higher than the control in the CUT. Students' science process skills positively predicted their conceptual understanding in biology.

Significance: Inquiry-based flipped classroom can be as effective as the non-flipped inquiry-based instruction in improving students' conceptual understanding and science process skills but can be made even more effective depending on the content, the manner the content is uploaded and the choice of LMS for uploading the online content. The study also showed the importance of science process skills in enhancing students' conceptual understanding in biology.

Keywords: Flipped classroom, conceptual understanding, science process skills.

\section{INTRODUCTION}

The Flipped Classroom Model is a teaching innovation that makes use of online digital technology to deliver lessons outside class while homework, discussions, and exercises are conducted in class (Jamaludin \& Osman, 2014). Bergman and Sams (2012) saw the need for a flexible learning environment to address the needs of their students. Scholars claimed that this innovation is one of the emerging means of delivering instruction that can facilitate student engagement (Jamaludin \& Osman, 2014). Researchers claimed that activities promoting interactive engagement on the part of the student have a positive impact on students' academic performance (Malefyane, Hofman, Winnips, \& Beetsma, 2014). Consequently, Bergman and Sams made this pedagogical innovation known to other educators and formed the Flipped Learning Network to fully equip teachers in implementing this model (Handam, Mcknight, Mcknight, \& Arfstrom, 2013).

In this pedagogical model, online digital tools, teaching approach and subject matter are important considerations in delivering instruction. Mishra and Koehler (2006) assert that effective instruction requires a merging of technological, pedagogical and content knowledge functioning as a single construct instead of viewing them as 
independent entities. Therefore, researchers of this study propose a Flipped Classroom Model for Science that combines the knowledge of online digital technology, science concepts (content), and scientific inquiry (pedagogy) into a single pedagogical construct. While past and present studies have already proven the impact of inquiry-based instruction on students (Shymansky, Hodges, \& Woodworth, 1990; Simsek \& Kabapinar, 2010), the ability of this pedagogical model to deliver a better learning outcome than a non-flipped inquiry-based model has to be further investigated.

Therefore this study intended to see if the use of online technology can enhance, negate or do not affect the impact of inquiry-based pedagogy in this pedagogical model. Thus, it seeks to find answers to the following:

1. Do students taught in the Inquiry-based Flipped Classroom Model show greater improvement in their conceptual understanding than those taught in the Non-flipped Inquirybased Approach?

2. Do students taught in the Inquiry-based Flipped Classroom Model show greater proficiency in science process skills than those taught in the Non-flipped Inquiry-based Approach?

3. Do science process skills positively predict students' conceptual understanding in biology?

\section{LITERATURE REVIEW}

\section{Flipped Learning}

Flipped Learning is a teaching strategy that makes use of a flexible learning environment (individual learning space) to help students learn lessons first hand and a dynamic, engaging environment (group space) where they apply what they learned from the lessons taught (Waltje, 2014). In other words, Flipped Learning uses online digital technology to learn content outside class, and engaging activities are conducted during class (Jamaludin \& Osman, 2014). Bergman and Sams (2012), proponents of this model, have discovered a more flexible learning environment that considers the needs of their students. The flipped classroom is now one of the many technology-based models that are currently changing the educational landscape. 
Such innovation stems from challenges regarding student engagement and student achievement in the classroom. Borg and Sapiro (1996) opine that the mismatch between the pedagogical style of the teacher and the learning style of students causes a decline in student interest and engagement in the subject matter. As a result, teachers become instruments of reproductive learning instead of active learning (Yerrick, Parke, \& Nugent, 1997). Therefore, the traditional model does not provide students with a learning environment that promotes challenging mental tasks (Gilboy, Heinerichs, \& Pazzaglia, 2015).

Studies on the impact of flipped classrooms have been constantly increasing. Shahnaz and Hussain (2016) claimed that the flipped classroom model can accommodate different learning styles of students while evidences of student engagement, motivation, improved communication and higher-order thinking skills have manifested. In a recent study, students under a blended learning instructional design (flipped classroom) showed higher academic performance in oriental music than students who received instruction in the traditional model (Edward, Asirvatham, \& Johar, 2019). Researchers in the field of mathematics education asserted that students who received instruction in a flipped classroom environment demonstrated greater improvement in linear algebra topics than those taught using the traditional model (Love, Hodge, Grandgenett, \& Swift, 2011). Amresh, Carberry, and Femiani (2013) stated that mean scores in computer programming for midterm and finals were significantly higher in the Flipped Classroom Group than the mean scores in the Traditional Group. Kong (2014) showed that the model has a significant positive impact on students' information literacy and in all areas of critical thinking.

Inquiry-based Flipped Classroom has started to gain ground in some academic institutions. Warter-Perez and Dong (2012) presented how interactive lectures through tablet PCs provide an inquiry-based environment outside class and application of learning during in-class activities is conducted through students' class projects. Musallam (2013) experimented with the Explore-Flip-Apply learning cycle using the flipped classroom model to support inquiry-driven lessons in his class. Inquiry-based flipped learning has been used in teaching STEM courses in universities, providing more class time for problem-solving tasks after content acquisition online (Love, Hodge, Corritore, \& Ernst, 2015). 


\section{Inquiry}

Inquiry is the discipline that scientists practice in order to study the natural world by formulating explanations based on empirical evidence (National Research Council, 2000). Inquiry is also a student-centered teaching strategy that allows students to construct knowledge by asking questions, conducting investigations, and analyzing data until a conclusion is formed (Bayram, Oskay, Erdem, Ozgur, \& Sen, 2013). The National Science Teachers Association (NSTA) opines that scientific inquiry promotes scientific understanding as students learn to investigate, gather data, formulate explanations and conclusions from their data (The Ohio Academy of Science, 2007). The Inter Academy Panel (IAP) asserts that the use of inquiry in education has been adapted in over 30 countries as a means to implement pedagogical reforms (Harlen \& Allende, 2009). The United Nations Educational Scientific and Cultural Organization (UNESCO) has recommended scientific inquiry to upgrade the quality of science education across the globe (Gee \& Wong, 2012).

Inquiry as a teaching approach gained ground in science education as previous and recent evidence-based research continue to validate its importance in the academe. Studies have shown that inquiry as a teaching strategy has a significant impact on student achievement, perceptions and process skills (Shymansky, Hedges, \& Woodworth, 1990). Significant improvements in students' science process skills and conceptual understanding of a particular elementary science lesson were evident when inquiry was used as a teaching strategy (Simsek \& Kabapinar, 2010). Furthermore, inquiry-based instruction can significantly enhance students' extrinsic goal motivation (Bayram, Oskay, Erdem, Ozgur, \& Sen, 2013). Duran and Dokme (2016) claimed that significant improvements in students' critical thinking were observed in an inquiry-based environment.

In the pursuit of promoting student participation in learning science, the National Science Education Standards (NSES) was drafted (Trowbridge \& Bybee, 1996). The NSES has enumerated the essential features of inquiry which pertain to behaviors that learners demonstrate in an inquiry-based learning environment. These behaviors that students demonstrate are: (1) engaging in scientifically-oriented questions; (2) prioritizing empirical evidence; (3) making explanations from evidence gathered or generated from 
investigations; (4) connecting their explanations to current scientific knowledge; and (5) communicating and justifying their proposed explanations (National Research Council, 2000).

\section{Conceptual Understanding}

Scholars differ in describing the word concept as well as how it is acquired. Platonists acknowledge the existence of the word, concept in the presence or absence of an observer while naturalists contend that concepts are produced by the interaction of the mind with the world (Barsalou, Simmons, Barbey, \& Wilson, 2003). The classical theory defines concept as having a collection of entities which serves as conditions for the object to meet and by meeting these conditions the object can be described or identified based on the entities under that concept (Cohen \& Murphy, 1984). Some define a concept as a set of meanings which possesses similarities, differences, relationships, and patterns observed (Koniceck-Moran \& Keeley, 2015).

The mind-world connection in the construction of concepts is associated with conceptual understanding. Viennot (2008) stated that conceptual understanding involves the application of an explanation to certain novel situations that are previously known. Sawyer (2008) claimed that conceptual understanding takes place when facts and procedures are applied in real-life situations. Koniceck-Moran and Keeley (2015) asserted that a deeper understanding of a concept is achieved when students apply it in a different situation, describe or define it in their own words, make a model of it, or find an appropriate metaphor for it.

One important aspect of conceptual understanding is its capacity to promote retention of lessons learned. Bahr and de Garcia (2010) stated that mental connections are established when facts and algorithms are learned with deeper understanding, making them easier to remember and use. This was bolstered through a study which assessed the conceptual understanding of pre-service primary school teachers on science topics like diffusion and osmosis by administering a pretest, post-test and delayed post-test. It showed that pre-service teachers improved significantly after the post-test while the means of their delayed post-test scores and post-test scores did not differ significantly, indicating that these teachers still recalled the concepts learned after a long period of time (Artun \& Costu, 2012). 


\section{Science Process Skills}

Science process skills are abilities that reflect how scientists think and act (Padilla, 1990). Ostlund (1998) believed that these skills are what scientists use in order to gain understanding when engaged in scientific investigations. Egger (2009) opined that integrating these skills in teaching helps students understand science processes in a more explicit manner. These skills are the basis of scientific thinking and research (Aydogdu, 2015).

Researchers investigated how science process skills affect students in the classroom. In terms of students' academic performance, findings from a meta-analysis study revealed that students who actively participated in tasks that required science process skills outperformed their counterparts who were taught in the traditional approach by 9 percentile points (Shymansky, Kyle, \& Alport, 1983). The use of teaching strategies that focused on these skills was proven to have a significant impact on the academic achievement of students (Abungu, Okere, \& Wachanga, 2014). Furthermore, past and recent studies have proved that the science process skills that students use in a particular subject matter can also be applied in another area or discipline (Tomera, 1974; Aydogdu, 2015).

\section{METHODOLOGY}

A two-group pretest/post-test design was conducted on Grade 9 students in a school located outside Metropolitan Manila, Philippines. The subjects had a median age of 15 years, and comprised 34 boys and 21 girls. In order to avoid disruption of normal class activities, the subjects were selected via purposive sampling method. One group comprising 28 students was designated as the experimental group. The experimental group (Flipped Inquiry Group) received their instruction through online videos and other online posts with accompanying inquiry-based questions. Application of what they learned from online posts/videos was conducted through group activities or discussions during class time. A Facebook community page was set up as a secret group for the Flipped Inquiry Group and functioned as a Learning Management System (LMS) where online lessons were uploaded when new content was introduced.

The control group (Non-Flipped Inquiry Group), on the other hand, comprised 27 students who received instruction in a conventional 
manner (non-flipped and inquiry-based). The content and lesson plan objectives of this group were similar to the Flipped Inquiry Group including the type of inquiry-based questions that comprised a formative assessment component of the lesson (Figure 1). The intervention lasted for seven weeks. Topics covered in this study were: Respiratory System, Circulatory System, Photosynthesis, Cellular Respiration, and non-Mendelian Genetics (Table 1).

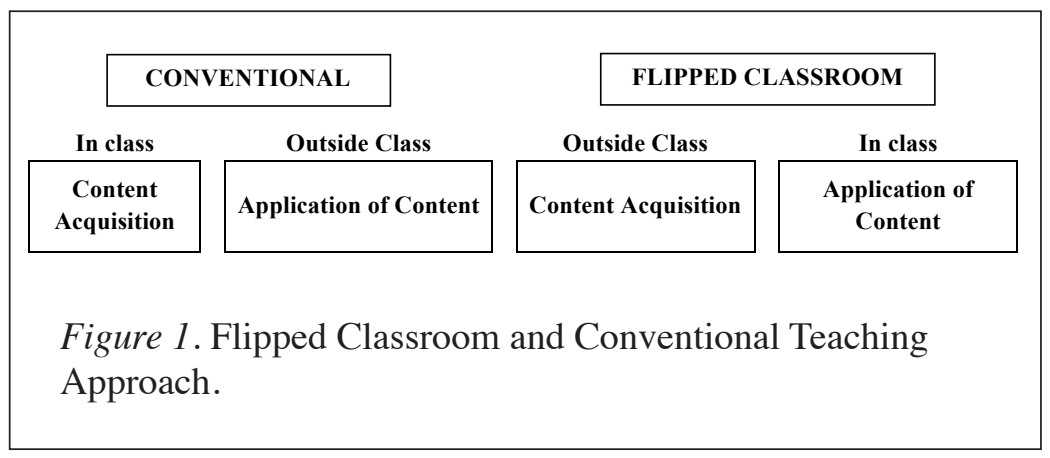

Table 1

Uploaded Online Lessons for the Flipped Inquiry Group

\begin{tabular}{|c|c|c|}
\hline Biology Topic & Uploaded Material & Topic \\
\hline \multirow[t]{2}{*}{ Respiratory System } & PowerPoint slide & $\begin{array}{l}\text { Construction of the Lung } \\
\text { Chest Model }\end{array}$ \\
\hline & Online video & $\begin{array}{l}\text { Construction and Use of } \\
\text { Improvised Spirometer }\end{array}$ \\
\hline \multirow[t]{3}{*}{ Circulatory System } & Online video & $\begin{array}{l}\text { Dissecting a mammalian } \\
\text { heart }\end{array}$ \\
\hline & PowerPoint slide & $\begin{array}{l}\text { Proper way of using a } \\
\text { sphygmomanometer }\end{array}$ \\
\hline & Online video & $\begin{array}{l}\text { Reading the systolic and } \\
\text { diastolic blood pressure }\end{array}$ \\
\hline Photosynthesis & Online video & $\begin{array}{l}\text { Setup demonstrating } \\
\text { Photosynthesis in Elodea }\end{array}$ \\
\hline Cellular Respiration & Online pictures & $\begin{array}{l}\text { Experimental setup using } \\
\text { Hydrilla }\end{array}$ \\
\hline $\begin{array}{l}\text { Non-Mendelian } \\
\text { Genetics }\end{array}$ & $\begin{array}{l}\text { Online post } \\
\text { (text form with Pun- } \\
\text { nett squares) }\end{array}$ & $\begin{array}{l}\text { Lesson on multiple alleles } \\
\text { with inquiry-based ques- } \\
\text { tions }\end{array}$ \\
\hline
\end{tabular}


The inquiry-based approach was the pedagogical component of the intervention for both groups. Embedded in the lesson plans for both groups were the essential features of inquiry recommended by the National Science Education Standards. These features were reflected in the questions and tasks that the students were engaged in.

A Conceptual Understanding Test (CUT) was developed to measure the amount of learning of the groups during the study. It was a 40item multiple choice test covering topics taught during the 7-week intervention period. The instrument assessed how students applied science concepts in certain situations and how they connected them to other concepts. The test was first validated by experts from reputable academic and research institutions in the country. These experts are science education specialists who have mastery of content and pedagogical approaches in science instruction at basic and tertiary education levels. With regard to the test's reliability, it posted a reliability coefficient of 0.79 during pilot testing and 0.882 , after the intervention.

Researchers of this study also developed a Science Process Skills Test (SPST) which also went through content validation. It was a 35-item multiple choice test which measured the following skills namely, inferring, predicting, controlling variables, and interpreting data. The test was pilot-tested and the reliability coefficient of the instrument was 0.897 . After the intervention, the reliability coefficient of the instrument was 0.82 .

Data from the CUT and SPST were collected before and after intervention. Pretest and post-test scores from the Flipped Inquiry and Non-Flipped Inquiry Groups were subjected to a normality test (Shapiro-Wilk test) to determine if data collected from both groups assumed normal distribution. Pretest and post-test mean scores from the Flipped Inquiry and Non-Flipped Inquiry Groups were then subjected to appropriate parametric testing. Means of the CUT and SPST pretest scores between the groups were compared to assess their initial comparability prior to the intervention. Means of the CUT and SPST post-test mean scores between the groups were analyzed to compare the impact of instruction in the Flipped Inquiry Group with the impact of instruction in the Non-Flipped Inquiry Group. Pretest and post-test mean scores for each group were compared to see if there were significant improvements in their CUT and SPST 
scores after the intervention. To determine if science process skills is a positive predictor of students' conceptual understanding, Pearson's correlation and linear regression analysis were conducted. The alpha level was set at $\alpha=.05$ for this study.

\section{RESULTS}

The CUT and SPST scores from both groups were subjected to a normality test before applying the appropriate statistical analysis. Based on the Shapiro-Wilk test, the pretest and post-test scores in the CUT and SPST assumed normal distribution suitable for appropriate parametric testing.

\section{Conceptual Understanding}

\section{Analysis of Pretest Mean Scores}

Pretest mean scores between the Flipped Inquiry Group ( $\mathrm{M}=15.39$, $\mathrm{SD}=4.47)$ and Non-Flipped Inquiry Group $(\mathrm{M}=16.00, \mathrm{SD}=4.27)$ were analyzed using two-tailed independent samples t-test. Results showed that the groups were comparable prior to the intervention $[\mathrm{t}(53)=-0.515, \mathrm{p}=.609]$

(Table 2).

Table 2

Comparison of CUT Pretest Mean Scores

\begin{tabular}{lcccccccc}
\hline & $\mathrm{N}$ & Mean & SD & SE & df & t & $\begin{array}{c}\text { Sig. } \\
\text { (two-tailed) }\end{array}$ \\
\hline $\begin{array}{l}\text { Flipped } \\
\text { Inquiry }\end{array}$ & 28 & 15.39 & 4.47 & 0.844 & & & \\
& & & & & & & & \\
$\begin{array}{l}\text { Non-Flipped } \\
\text { Inquiry }\end{array}$ & 27 & 16 & 4.27 & 0.822 & & & \\
\hline
\end{tabular}


Table 3

Comparison of CUT Pretest Mean Scores Grouped according to Topic

\begin{tabular}{|c|c|c|c|c|c|c|c|c|c|}
\hline \multicolumn{4}{|c|}{ Flipped Inquiry } & \multicolumn{6}{|c|}{ Non-Flipped Inquiry } \\
\hline Topics & Mean & $\mathrm{SD}$ & SE & Mean & SD & SE & df & $\mathrm{t}$ & $\begin{array}{c}\text { Sig. } \\
\text { (two-tailed) }\end{array}$ \\
\hline Respirators Sys & 4.39 & 1.93 & 0.365 & 4.67 & 1.73 & 0.333 & 53 & -0.553 & 0.583 \\
\hline $\begin{array}{l}\text { Circulatory } \\
\text { System }\end{array}$ & 4.5 & 1.71 & 0.323 & 4.92 & 2.18 & 0.42 & 53 & -0.807 & 0.423 \\
\hline $\begin{array}{l}\text { Respiration \& } \\
\text { Photosynthesis }\end{array}$ & 2.79 & 1.07 & 0.202 & 2.7 & 1.3 & 0.249 & 53 & 0.257 & 0.798 \\
\hline $\begin{array}{l}\text { non-Mendelian } \\
\text { Genetic }\end{array}$ & 3.71 & 1.65 & 0.312 & 3.7 & 1.27 & 0.244 & 53 & 0.027 & 0.979 \\
\hline
\end{tabular}

The pretest mean scores of the groups for each biology topic were also compared. Results of independent samples t-test showed that the pretest mean scores for both groups were comparable for all the topics before the intervention (Table 3).

\section{Analysis of Post-test Mean Scores}

The CUT Post-test mean scores of the two groups after the intervention were compared using independent samples t-test. Results showed that the Flipped Inquiry Group $(\mathrm{M}=25.86, \mathrm{SD}=7.66)$ and the Non-Flipped Inquiry Group (M=24.15, SD = 8.28) did not differ significantly in the Conceptual Understanding Test $[\mathrm{t}(53)=0.795, \mathrm{p}$ $=0.86]$ (Table 4).

Table 4

Comparison of CUT Posttest Mean Scores

\begin{tabular}{lccccccc}
\hline & $\mathrm{N}$ & Mean & SD & SE & Df & t & Sig. (two-tailed) \\
\hline $\begin{array}{l}\text { Flipped } \\
\text { Inquiry }\end{array}$ & 28 & 25.86 & 7.66 & 1.45 & & & \\
& & & & & 53 & 0.795 & 0.86 \\
$\begin{array}{l}\text { Non- } \\
\text { Flipped } \\
\text { Inquiry }\end{array}$ & 27 & 24.15 & 8.28 & 1.59 & & & \\
\hline
\end{tabular}


The post-test mean scores between the Flipped Inquiry and the NonFlipped Inquiry Groups for each topic covered in the CUT were compared using independent samples t-test. Results showed that students in the Flipped Inquiry Group scored significantly higher than the Non-Flipped Inquiry Group in non-Mendelian Genetics [ $\mathrm{t}$ $(53)=2.198, \mathrm{p}=.032]($ Table 5).

\section{Table 5}

Comparison of CUT Posttest Mean Scores Grouped according to Topic

\begin{tabular}{|c|c|c|c|c|c|c|c|c|c|}
\hline \multicolumn{4}{|c|}{ Flipped Inquiry } & \multicolumn{6}{|c|}{ Non-Flipped Inquiry } \\
\hline Topics & Mean & $\mathrm{SD}$ & SE & Mean & $\mathrm{SD}$ & SE & $\mathrm{df}$ & $\mathrm{t}$ & $\begin{array}{c}\text { Sig. } \\
\text { (two-tailed) }\end{array}$ \\
\hline Respirators Sys & 6.14 & 1.86 & 0.352 & 6.26 & 2.19 & 0.422 & 53 & -0.212 & 0.832 \\
\hline $\begin{array}{l}\text { Circulatory } \\
\text { System }\end{array}$ & 8.43 & 2.82 & 0.533 & 7.52 & 3.42 & 0.659 & 53 & 1.078 & 0.286 \\
\hline $\begin{array}{l}\text { Respiration \& } \\
\text { Photosynthesis }\end{array}$ & 3.39 & 1.57 & 0.297 & 4.00 & 1.94 & 0.374 & 53 & -0.128 & 0.208 \\
\hline $\begin{array}{l}\text { non-Mendelian } \\
\text { Genetic }\end{array}$ & 7.69 & 2.49 & 0.47 & 6.37 & 2.88 & 0.555 & 53 & 2.198 & $0.032 *$ \\
\hline
\end{tabular}

$* \mathbf{p}<.05$

\section{Analysis of Pretest and Post-test Mean Scores}

The CUT pretest and post-test mean scores for each group were compared using paired samples t-test to determine if there was a significant increase in their conceptual understanding after the 7-week intervention (Table 6). It showed that the CUT mean scores before and after the intervention differed significantly in the Flipped Inquiry Group and in the Non-Flipped Inquiry Group. 
Table 6

Comparison of CUT Pretest and Posttest mean Scores in the Flipped and Non-Flipped Inquiry Groups

\begin{tabular}{lcccccccc}
\hline & & $\mathrm{N}$ & Mean & SD & SE & Df & t & Sig. (two-tailed) \\
\hline $\begin{array}{l}\text { Flipped } \\
\text { Inquiry }\end{array}$ & Pre & 28 & 15.39 & 7.66 & 0.844 & 27 & 8.141 & $\mathbf{0 . 0 0 0 *}$ \\
& Post & 28 & 25.86 & 4.47 & 1.45 & & & \\
$\begin{array}{l}\text { Non-Flipped } \\
\text { Inquiry }\end{array}$ & Pre & 27 & 16 & 4.27 & 0.822 & 26 & 6.999 & $\mathbf{0 . 0 0 0 *}$ \\
& Post & 27 & 24.15 & 8.28 & 1.59 & & & \\
\hline
\end{tabular}

*p<.001 (highly significant)

\section{Science Process Skills}

\section{Analysis of SPST Mean Scores Prior to Intervention}

The SPST pretest mean scores of the Flipped Inquiry Group ( $\mathrm{M}=$ 15.76, SD = 6.62) and Non-Flipped Inquiry Group $(M=17.27, S D$ $=5.87$ ) were analyzed using independent samples t-test (Table 7). Results showed that the SPST pretest mean scores of the two groups did not differ significantly $[\mathrm{t}(41)=-.793, \mathrm{p}=.216]$ and therefore they were comparable prior to intervention.

\section{Table 7}

Comparison of SPST Prestest Mean Scores

\begin{tabular}{lccccccc}
\hline & $\mathrm{N}$ & Mean & SD & SE & Df & t & Sig. (two-tailed) \\
\hline $\begin{array}{l}\text { Flipped } \\
\text { Inquiry }\end{array}$ & 21 & 15.76 & 6.62 & 1.44 & & & \\
& & & & & 41 & -0.793 & 0.216 \\
$\begin{array}{l}\text { Non-Flipped } \\
\text { Inquiry }\end{array}$ & 22 & 17.27 & 5.97 & 1.25 & & & \\
\hline
\end{tabular}

A comparison of the SPST pretest mean scores of the two groups for each science process skill was also conducted. The skills included in this study were inferring, predicting, controlling variables, and interpreting data (Table 8). Results from the pretest mean scores 
of the two groups for each science process skill did not differ significantly $(\mathrm{p}>.05)$ and therefore they were comparable for each skill before the intervention.

Table 8

Comparison of SPST Pretest Mean Scores per Science Process Skill

\begin{tabular}{lcccccccccc}
\hline \multicolumn{1}{c}{ Flipped Inquiry } & \multicolumn{7}{c}{ Non-Flipped Inquiry } & & \\
& Mean & SD & SE & Mean & SD & SE & df & t & $\begin{array}{c}\text { Sig. } \\
\text { (two-tailed) }\end{array}$ \\
\hline $\begin{array}{l}\text { Inferring } \\
\text { Predicting }\end{array}$ & 1.05 & 0.67 & .15 & 1.14 & 0.71 & .15 & 41 & -.421 & 0.676 \\
$\begin{array}{l}\text { Controlling } \\
\text { variables }\end{array}$ & 3.1 & 1.92 & .42 & 2.91 & 1.31 & .28 & 41 & .373 & 0.711 \\
$\begin{array}{l}\text { Interpreting } \\
\text { data }\end{array}$ & 8.1 & 3.79 & .828 & 9.41 & 3.5 & .746 & 41 & -1.181 & 0.244 \\
\hline
\end{tabular}

Analysis of SPST Post-test Mean Scores

The SPST post-test mean scores of the Flipped Inquiry $(\mathrm{M}=18.29$, $\mathrm{SD}=6.72)$ and Non-Flipped Inquiry Groups $(\mathrm{M}=20.55, \mathrm{SD}=5.32)$ were compared (Table 9). Results from the independent samples t-test showed that there was no significant difference between the two groups $[\mathrm{t}(41)=-1.226, \mathrm{p}=.226]$.

Table 9

Comparison of Posttest Mean Scores in the Science Process Skills Test

\begin{tabular}{lccccccc}
\hline & $\mathrm{N}$ & Mean & $\mathrm{SD}$ & $\mathrm{SE}$ & $\mathrm{Df}$ & $\mathrm{t}$ & Sig. (two-tailed) \\
\hline $\begin{array}{l}\text { Flipped } \\
\text { Inquiry }\end{array}$ & 21 & 18.29 & 6.72 & 1.47 & & & \\
& & & & & 41 & -1.226 & 0.226 \\
$\begin{array}{l}\text { Non-Flipped } \\
\text { Inquiry }\end{array}$ & 22 & 20.55 & 5.32 & 1.14 & & & \\
\hline
\end{tabular}


The SPST mean post-test scores for each process skill was also compared. Findings from the independent samples t-test revealed that there was no significant difference between the Flipped Inquiry and Non-Flipped Inquiry Groups for each science process skill covered in the SPST (Table 10).

Table 10

Comparison of Posttest Mean Scores per Science Process Skill

\begin{tabular}{|c|c|c|c|c|c|c|c|c|c|}
\hline \multicolumn{4}{|c|}{ Flipped Inquiry } & \multicolumn{6}{|c|}{ Non-Flipped Inquiry } \\
\hline & Mean & $\mathrm{SD}$ & $\mathrm{SE}$ & Mean & $\mathrm{SD}$ & SE & df & $\mathrm{t}$ & $\begin{array}{c}\text { Sig. } \\
\text { (two-tailed) }\end{array}$ \\
\hline Inferring & 0.9 & 0.7 & .15 & 1.27 & 0.77 & .16 & 41 & -1.64 & 0.11 \\
\hline Predicting & 3.86 & 1.88 & .41 & 4.36 & 1.73 & .37 & 41 & -.919 & 0.364 \\
\hline $\begin{array}{l}\text { Controlling } \\
\text { variables }\end{array}$ & 3.71 & 2.08 & .453 & 4.05 & 1.53 & .326 & 41 & -.598 & 0.554 \\
\hline $\begin{array}{l}\text { Interpreting } \\
\text { data }\end{array}$ & 9.81 & 3.59 & .783 & 10.86 & 3.37 & .719 & 41 & -.994 & 0.326 \\
\hline
\end{tabular}

Analysis of Pretest and Post-test Mean Scores

The means of the SPST scores before and after instruction for each group were compared using paired samples t-test to determine if significant improvements in the students' science process skills occurred after instruction (Table 11). Results showed that the SPST post-test mean scores of the Flipped Inquiry and Non-Flipped Groups were significantly higher than their respective SPST pretest mean scores.

Table 11

Comparison of SPST Pretest and Posttest Mean Scores of the Flipped and Non-Flipped Inquiry Groups

\begin{tabular}{lcccccccc}
\hline & & $\mathrm{N}$ & Mean & SD & SE & Df & t & $\begin{array}{c}\text { Sig. } \\
\text { (two-tailed) }\end{array}$ \\
\hline Flipped Inquiry & Pre & 21 & 15.76 & 6.62 & 1.45 & 20 & -2.677 & $\mathbf{0 . 0 1 4 *}$ \\
& Post & 21 & 18.29 & 6.72 & 1.47 & & & \\
$\begin{array}{l}\text { Non-Flipped } \\
\text { Inquiry }\end{array}$ & Pre & 22 & 17.27 & 5.87 & 1.25 & & & \\
& Post & 22 & 20.55 & 5.32 & 1.14 & & & \\
\hline
\end{tabular}

$* \mathbf{p}<.05$

Science Process Skills as Predictors of Conceptual Understanding 
Linear regression analysis showed that science process skills accounted for $43.5 \%$ of the variations in the conceptual understanding post-test scores $\left(\mathrm{R}^{2}=.435, \mathrm{~F}(1,42)=32.35, \mathrm{p}<.001\right)$. Results showed that students' science process skills significantly predicted their level of conceptual understanding of selected biology topics $(\mathrm{B}=0.816$, $\mathrm{p}<.001$ ) (Table 12).

Table 12

Regression Analysis Summary for Science Process Skills Predicting Conceptual Understanding

\begin{tabular}{cccccc}
\hline Variable & $\mathrm{B}$ & $95 \% \mathrm{CI}$ & $\beta$ & $\mathrm{t}$ & $\mathrm{p}$ \\
\hline Constant & 10.100 & {$[4.26,15.938]$} & & 3.491 & 0.001 \\
SPS post & 0.816 & {$[.527,1.106]$} & 0.660 & 5.688 & 0.000 \\
\hline
\end{tabular}

Note $\mathrm{R}^{2}=.435$

$\mathrm{CI}=$ Confidence Interval for B

\section{DISCUSSION AND CONCLUSION}

Although both groups (Flipped Inquiry and Non-Flipped Inquiry Groups) improved significantly after intervention, the study proved that inquiry-based flipped learning did not give students a significant advantage over non-flipped inquiry-based instruction in terms of students' conceptual understanding of most of the biology topics covered during the intervention period. The study also proved that students in an inquiry-based flipped classroom environment did not become more or less proficient in their science process skills than those taught in a non-flipped inquiry-based learning environment.

It is only in one biology topic, non-Mendelian Genetics that the Flipped Inquiry Group performed better than the Non-Flipped Inquiry Group in the CUT. Possible explanations for the significantly higher post-test mean of the Flipped Inquiry Group over the NonFlipped Inquiry Group in non-Mendelian Genetics could be attributed mainly to the following factors: (1) the kind of Learning Management System (LMS) used in this study; (2) the nature of the content; and (3) how the content was uploaded. These factors may 
have had a synergistic impact on why the lesson on non-Mendelian Genetics delivered a better learning outcome in students' conceptual understanding.

Firstly, the online content was uploaded in their favourite social media which served as their LMS. The table below shows the per cent of students in the Flipped Inquiry Group who responded to the notifications in the Facebook Grade 9 Biology Group (serving as LMS) for each topic uploaded online, indicating the effectiveness of social media in making online content accessible outside class (Table 14). Previous studies showed evidence of a positive relationship (B $=0.42, \mathrm{p}<.00)$ between a popular social media platform (Twitter) and the level of student engagement in a certain course while use of a traditional LMS failed to have a significant impact $(\mathrm{B}=.09 \mathrm{p}$ $=0.48$ ) on their level of involvement (Williams \& Whiting, 2016). Another study showed that most of the students who participated in the Facebook group demonstrated active involvement based on a social media analytics software that monitored the interactions of students online (Foogooa \& Ferdinand-James, 2017). This is a pertinent finding because there is a positive relationship between student engagement and student achievement (Kuh, 2009).

So, why did the students in the Flipped Inquiry Group perform better than the Non-Flipped Inquiry Group in non-Mendelian Genetics than the rest of the biology topics (Respiratory System, Circulatory System, Cellular Respiration, and Photosynthesis)? In comparing the former topic with the rest of the topics, this online lesson was supported by a prerequisite lesson in the previous year where similar concepts and skills were learned. Prior to this Grade 9 topic, the students had learnt Mendelian Genetics in their 8th grade. Concepts like dominant and recessive genes and how these genes were expressed was learnt in their Grade 8 lesson on Genetics. Students were also familiar with Punnett squares and how they were used to estimate the probability of traits expressed in offsprings because Punnett squares were also used in their Grade 8 Mendelian Genetics lesson. With regard to the format of uploading content, the lesson on multiple alleles did not use videos, photographs or PowerPoint presentations which were utilized in other lessons in this Grade 9 unit. Instead, the online lesson on multiple alleles was posted on the Facebook wall, including information and inquiry-based questions for the students to think about. When internet signals become weak, uploaded videos may run slow, pictures may not be fully displayed 
and can therefore affect students' engagement in the topic. Thus, easy access to online information may be instrumental in the online acquisition of content in a flipped classroom environment.

Table 13

Student who Responded to the Notifications in the Facebook Group Serving as Their LMS

\begin{tabular}{llc}
\hline \multicolumn{1}{c}{ Biology Topic } & \multicolumn{1}{c}{ Topic } & $\begin{array}{c}\text { \% of students who } \\
\text { responded to the } \\
\text { notification }\end{array}$ \\
\hline Respiratory System & $\begin{array}{l}\text { Construction of the Lung } \\
\text { Chest Model }\end{array}$ & $100.0 \%$ \\
& $\begin{array}{l}\text { Construction and Use of } \\
\text { Improvised Spirometer } \\
\text { Dissecting a mammalian } \\
\text { heart }\end{array}$ & $96 \%$ \\
Circulatory System & $\begin{array}{l}\text { Proper way of using a } \\
\text { sphygmomanometer }\end{array}$ & $86 \%$ \\
& $\begin{array}{l}\text { Reading the systolic and } \\
\text { diastolic blood pressure } \\
\text { Setup demonstrating Photo- } \\
\text { synthesis in Elodea }\end{array}$ & $96 \%$ \\
Photosynthesis & $\begin{array}{l}\text { Experimental setup using } \\
\text { Cellular Respiration } \\
\text { Hydrilla }\end{array}$ & $96 \%$ \\
\hline & $\begin{array}{l}\text { Lesson on multiple alleles } \\
\text { with inquiry-based questions }\end{array}$ & $96 \%$ \\
\hline
\end{tabular}

Results of the linear regression showed that students' science process skills positively predicted their level of conceptual understanding in biology. The results were supported by another correlational study that sought to establish connections between science process skills and conceptual understanding in a certain physics topic (Sari, Sudargo, \& Priyandoko, 2018). However, it did not establish which variable was the predictor of the other. Establishing science 
process skills as the positive predictor of conceptual understanding is valuable information for teachers in order for them to prioritize science process skills that foster a more in-depth understanding of scientific ideas.

The results of the study showed that Inquiry-based Flipped Classroom Model could still be useful for teachers who struggle to cover the required topics in a unit when contact time is limited. The researchers of this study also recommended that Inquiry-based Flipped Classroom Model be utilized for lessons that need enrichment for fast learners if more contact time was used in accommodating underperforming students. The flexible learning environment of the flipped classroom environment could allow students to have more time developing their proficiency in certain skills in science before coming to class. For instance, they can have an online presentation of photomicrographs or videos of cells undergoing mitosis before they meet in class. When the students come to class, they will have some confidence in classifying the various stages of mitosis that cells undergo when examined under a microscope.

The study also provided valuable information for teachers regarding selection of an appropriate LMS that appeals to students, the nature of the content to be uploaded and the manner of uploading it to facilitate better student engagement. Furthermore, the study also recommended that academic supervisors motivate their teachers to prepare inquiry-based lessons with more extensive exposure to science process skills that can help foster deeper conceptual understanding. These minor reforms can be best achieved by requiring their teachers to incorporate the necessary process skills in their lesson plan objectives during lesson planning.

Other impact studies share similarities and differences with the results of this study. In an impact study conducted by the Harvey Mudd College faculty, there was no significant difference between those who were taught through a flipped problem-based learning (PBL) approach and those taught in a non-flipped PBL approach (Yong, Levy, \& Lape, 2015). However, there was no mention of the reliability of the instrument. Findings from the researchers of Brigham Young University in their quasi-experimental study also showed that there was no significant difference between students taught in a Flipped 5E learning cycle approach and those taught in Non-flipped 5E learning cycle approach in terms of scientific 
reasoning skills; however the researchers could not determine its impact on concept comprehension because of the low reliability of their instrument (Jensen, Kummer, \& Godoy, 2015).

These previous studies compared overall post-test and pretest mean scores and did not proceed with sublevel analysis which compares the mean scores of the groups for each topic covered in the entire intervention period. These studies had not considered that content is best delivered not only with appropriate pedagogy but also with appropriate technology specific to the particular content. Under the framework of Technological Pedagogical Content Knowledge by Mishra and Koehler (2006), mere additions to technology would require a thorough understanding of how technology interrelates with pedagogy and content. This present study acknowledges Mishra and Koehler's (2006) perspective which served as bases for the varied representations of online content for each biology topic. Thus, instructional designers must exercise discretion in the use of technology in the teaching-learning process. Ogunbase (2016) stated that in the use of web-based learning environments (WBLE) neglecting pedagogical design and pedagogical usability could lead to a failed learning experience.

Critics of the flipped classroom model should also realize that there is a need for a thorough understanding of its implementation including the variations in individual and group learning space. Opponents of the flipped classroom model state that the model only reverses the manner of delivering lessons since lessons are still lecture-based even when presented online (Wright, 2012). On the contrary, flipped classroom models are opportunities for instructional designers to make online content more appealing to learners as online technology can be used to deliver videos, interactive learning objects (LO), or PowerPoint presentations. A study conducted by Mzoughi (2015) claimed that students preferred web-enhanced courses over traditional forms of instruction. In fact, the flexible learning environment is perceived to be a means for differentiated instruction that can cater to the varied learning styles of students (Lage, Platt, \& Treglia, 2000).

On the other hand, other critics are skeptical of the capability of teachers to develop ICT mediated curriculum material delivered online (Du, Fu, \& Wang, 2014) even though, Jonathan Bergman and Aaron Sams, pioneers of the flipped classroom model, are high school chemistry teachers and not IT professionals. In the development of 
curriculum materials, the National Advisory Committee on Creative and Cultural Education asserts that creativity in teaching is vital to make teaching more effective and interesting (Jeffrey \& Craft, 2010). Weisberg (2006) asserts that mastery of content knowledge is essential for creativity to manifest. Thus, innovations in developing online curriculum material are possible if teachers have a strong mastery of content which is a personal responsibility in their professional practice.

\section{ACKNOWLEDGEMENTS}

This research received no specific grant from any funding agency.

\section{REFERENCES}

Abungu, H. E., Okere, M.I.O., \& Wachanga, S.W. (2014). The effect of science process skills teaching approach on secondary school students' achievement in chemistry in Nyando District, Kenya. Journal of Educational and Social Research, 4(6), 359-371. doi:10.5901/jesr.2014.v4n6p359

Amresh, A., Carberry, A. R., \& Femiani, J. (2013). Evaluating the effectiveness of flipped classrooms

for teaching CS1. Paper presented at Frontiers in Education Conference. Oklahoma City, Oklahoma. doi:10.1109/ FIE.2013.6684923

Artun, H., \& Costu, B. (2012). Effect of the 5E model on prospective teachers' conceptual understanding of diffusion and osmosis. Journal of Science Education and Technology, 22, 1-10. doi:10.1007/s10956-012-9371-2

Aydogdu, B. (2015). The investigation of science process skills of science teachers in terms of some variables. Educational Research and Reviews, 10(5), 582-594. doi: 10.5897/ ERR2015.2097

Bahr, D. L., \& de Garcia, L. A. (2010). Elementary mathematics is anything but elementary. Belmont CA: Cengage Learning.

Barsalou, L. W., Simmons, W. K., Barbey, A. K., \& Wilson, C. D. (2003). Grounding conceptual knowledge in modalityspecific systems. Trends in Cogntive Sciences, 7(2), 84-91. doi: 10.1016/S1364-6613(02)00029-3 
Bayram, Z., Oskay, O. O., Erdem, E., Ozgur, S. D., \& Sen, S. (2013). Effect of inquiry-based learning method on student motivation. Procedia-Social and Behavioral Sciences, 106, 988-996. doi:10.1016/j.sbspro.2013.12.112

Bergman, J., \& Sams, A. (2012). Flip your classroom: Reach every student in every class everyday. Retrieved from http:// www.ascd.org/Publications/Books/Overview/Flip-YourClassroom.aspx.

Borg, M. O., \& Shapiro, S. L. (1996). Personality type and student performance in principles of economics. The Journal of Economic Education, 27(1), 3-25. doi:10.2307/1183005

Cohen, B., \& Murphy, G. L. (1984). Models of concepts. Cognitive Science, 8(1), 27-58. doi: 10.1207/s155 16709cog0801_2

Du, S. C., Fu, Z. T., \& Wang, Y. (2014, April). The flipped classroom - advantages and challenges. Paper presented at the International Conference on Economic Management and Trade Cooperation, Xi'an, China.

Duran, M., \& Dokme, I. (2016). The effect of the inquiry-based learning approach on students' critical thinking skills. Eurasia Journal of Mathematics, Science and Technology Education 12(12), 2887-2908. doi: 10.12973/eurasia.2016.02311a

Edward, C. N., Asirvatham, D., \& Johar, M. G. M. (2019). The impact of teaching oriental music using blended learning approach. Malaysian Journal of Learning and Instruction, 16(1), 81-103. Retrieved from http://mjli.uum.edu.my/ images/vol.16no.1/81-103.pdf

Egger, A. E. (2009). How do I teach the process of science? Pedagogy in action. Retrieved from https://serc.carleton.edu/sp/library/ process_of_science/how_process_science.html.

Foogooa, R., \& Ferdinand-James, D. (2017). Use of Facebook for enhancing student engagement in a higher education blended engineering course. Innovative Issues and Approaches in Social Sciences, 10(1), 8-30. doi: 10.12959/issn.1855-0541. IIASS-2017-no1-art1

Gee, K. A., \& Wong, K. K. (2012). A cross national examination of inquiry and its relationship to student performance in science: Evidencefrom the programforInternationalStudentAssessment (PISA) 2006. International Journal of Education Research, 53, 303-318. Retrieved from http://www.sciencedirect.com/ science/article/pii/S0883035512000365?np=y.

Gilboy, M., Heinerichs, S., \& Pazzaglia, G. (2015). Enhancing student engagement using flipped classroom. Journal 
of Nutrition Education and Behavior, 47(1), 109-114. Retrieved from http://www.sciencedirect.com/science/article/ pii/ S1499404614006381\#.

Handam, N., McKnight, P., McKnight, K., \& Arfstrom, K. M. (2013). A review of flipped learning [PDFfile]. Retrieved from http:// www.flippedlearning.org/review.

Harlen,W.,\&Allende,J.E.(2009).Teacher professional development in pre-secondary school inquiry -based science education. Santiago Chile: Fundacion para Estudios Biomedicos Avanzados de la Facultad de Medicina. Retrieved from http:// www.interacademies.net/File.aspx?id=9348.

Jamaludin, R., \& Osman, S.Z. (2014). The use of a flipped classroom to enhance engagement and promote active learning. Journal of Education and Practice, 5(2), 124-131. Retrieved from http:// www.iiste.org/Journals/index.php/JEP/article/view/10648.

Jeffrey, B., \& Craft, A. (2010). Teaching creatively and teaching for creativity: Distinctions and relationships. Educational Studies, 30(1), 77-87. doi:10.1080/0305569032000159750

Jensen, J. L., Kummer, T. A., \& Godoy, P. D. (2014). Improvements from a flipped classroom may simply be the fruits of active learning. CBE-Life Sciences Education, 14, 1-12.doi:10.1187/ cbe.14-08 -0129

Kong, S. C. (2014). Developing information literacy and critical thinking skills through domain knowledge learning in digital classrooms: An experience of practicing flipped classroom strategy. Computers \& Education, 78, 160-173. doi: 10.1016/j. compedu.2014.05.009

Koniceck-Moran, R., \& Keeley, P. (2015). Teaching for conceptual understanding in science. NSTA Press: Arlington.

Kuh, G. D. (2009). What student affairs professionals need to know about student engagement. Journal of College Student Development, 50(6), 683-706.

Lage, M. J., Platt, G. J., \& Treglia, M. (2000). Inverting the classroom: A gateway to creating an inclusive learning environment. The Journal of Economic Education, 31(1), 3043. doi:10.1080/00220480009596759.

Love, B., Hodge, Grandgenett, N., \& Swift, A. W. (2014). Student learning and perceptions in a Flipped linear algebra course. International Journal of Mathematics Education in Science and Technology, 45(3), 317-324. doi:10.1080/0020739X.20 13.822582 
Love, B., Hodge, A., Corritore, C., \& Ernst, D. C. (2015). Inquirybased learning and the flipped classroom model. PRIMUS, 25(8), 745-762. doi: 10.1080/10511970.2015.1046005

Malefyane, T., Hofman, A., Winnips, K., \& Beetsma, Y. (2014). The impactofinteractiveengagementmethodsonstudents'academic achievement. Higher Education Research and Development, 33(5), 1020-1034. doi: 10.1080/07294360.2014.890571.

Mishra, P., \& Koehler, M. J. (2006). Technological pedagogical content knowledge: A framework for teacher knowledge. Teachers College Record, 108(6), 1017-1054.

Musallam, R. (2013). A pedagogy-first approach to the flipped classroom. OnCue Journal, 35(1), 6-8. Retrieved from http:// www.cue.org/sites/cue.org/files/images/Spring13OnCUE.pdf

Mzoughi, T. (2015). An investigation of student web activity in a "flipped" introductory physics class. Procedia- Social and Behavioral Sciences, 191, 235-240. doi:10.1016/j. sbspro.2015.04.558

National Research Council. (2000). Inquiry and the National Science Education Standards: A guide for teaching and learning. Washington D. C.: National Academy Press. Retrieved from http://www.nap.edu/openbook.php?record_ $\mathrm{id}=9596$ \&page $=25$

Ogunbase, A. O. (2016). Pedagogical design and pedagogical usability of web-based learning environments: Comparative cultural implications from Africa and Europe (Academic Dissertation). School of Information Sciences, Tampere, Finland.

Ostlund, K. (1998). What the research says about the science process skills. Electronic Journal of Science Education. Retrieved from http://ejse.southwestern.edu/article/view/7589/5356.

Padilla, M. J. (1990). The science process skills. Research matters to the science teacher, 9004. Retrieved from https://www.narst. org/publications/research/skill.cfm.

Sari, P. M., Sudargo, F., \& Priyandoko, D. (2018). Correlation among science process skill, concept comprehension, and scientific attitude on regulation system materials. Presented at $1 \mathrm{st}$

International Conference of Education on Sciences, Technology, Engineering and Mathematics. (2017). Jakarta, Indonesia. United Kingdom: IOP Publishing.

Sawyer, R. K. (2008). Optimising learning: Implications of learning science research. Innovating to learn, learning to innovate. (pp. 45- 65). doi: 10.1787/9789264047983-en 
Shahnaz, S. M. F., \& Hussain, R. M. R. (2016). Designing instruction for active and reflective learners in the flipped classroom. Malaysian Journal of Learning and Instruction, 13(2), 147-173. Retrieved from https://files.eric.ed.gov/fulltext/ EJ1134740.pdf

Shymansky, J. A., Hedges, L. V., \& Woodworth, G. (1990). A reassessment of the effects of inquiry-based science curricula of the 60's on student performance. Journal of Research in Science Teaching, 27(2), 127-144.

Shymansky, J. A., Kyle Jr., W. C., \& Alport, J. M. (1983). The effects of new science curricula on student performance. Journal of Research in Science Teaching, 20(5), 387-404.

Simsek, P., \& Kabapinar, F. (2010). The effects of inquiry-based learning on elementary students' conceptual understanding of matter, scientific process skills, and science attitudes. Procedia-Social and Behavioral Sciences, 2(2), 1190-1194. Retrieved from http://www.sciencedirect.com/science/article/ pii/S1877042810002107\#

The Ohio Academy of Science. (2007). The Ohio core curriculum: What's required for science. Retrieved from http://www. ohiosci.org.

Tomera,A.N. (1974). Transfer and retention of transfer of the science process of observation and comparison in junior high school students. Science Education, 58(2), 195-203. doi: 10.1002/ sce. 3730580209.

Trowbridge, L. W., \& Bybee, R. W. (1996). Teaching secondary school science. New Jersey: Prentice Hall.

Viennot, L. (2008). Learning and conceptual understanding: Beyond simplistic ideas, what have we learned? In M. Vincentini, \& E. Sassi (Eds.), Connecting research in physics education with teacher education (pp. 1-17). International and Pan American Copyright Conventions:

International Commission on Physics Education. Retrieved from http://iupap-icpe.org/publications/teach2/index.html.

Waltje, J. (2014). Language learning technology review. The IALLT Journal, 44(1), 85-94. Retrieved from https://ialltjournal.org/ index.php/ialltjournal/article/viewFile/80/71.

Warter-Perez, N., \& Dong, J. (2012). Flipping the classroom: How to embed inquiry and design projects into a digital engineering lecture. Proceedings of the 2012 ASEE PSW Section Conference. Retrieved from http://aseepsw2012.calpoly.edu/ site_media/uploads/proceedings/papers/10B_35_ASEE_ PSW_2012_Warter-Perez.pdf 
Weisberg, R. (2006). Expertise and reason in creative thinking: Evidence from case studies and the laboratory. In J. Kaufman, \& J. Baer (Eds.), Creativity and Reason in Cognitive Development (pp. 7-42). Cambridge: Cambridge University Press. doi:10.1017/CBO9780511606915.003

Williams, D., \& Whiting, A. (2016). Exploring the relationship between student engagement, Twitter, and a learning management system: A study of undergraduate marketing students. International Journal of Teaching and Learning in Higher Education, 28(3), 302-313.

Wright, S. (2012, October 12). The flip: end of a love affair. Powerful Learning Practice. Retrieved from http://plpnetwork. com/2012/10/08/flip-love-affair/

Yerrick, R., Parke, H., \& Nugent, J. (1997). Struggling to promote deeply rooted change: The "filtering effects" of teachers' beliefs on understanding transformational views of teaching science. Science Education, 81(2), 137-159.

Yong, D., Levy, R., \& Lape, N. (2015). Why no difference? A controlled flipped classroom study for an introductory differential equations course. PRIMUS, 25(9-10), 907-921. 